\title{
Voltammetric Behavior of Nitrofurazone and its Hydroxymethyl Prodrug with Potential Anti-Chagas Activity
}

\author{
Mauro Aquiles La-Scalea ${ }^{*, a, b}$, Carla Maria de Souza Menezes ${ }^{a}$, Murilo Sérgio da Silva Julião ${ }^{b, c}$, \\ Man Chin Chung ${ }^{d}$, Sílvia Helena Pires Serrano ${ }^{b}$ and Elizabeth Igne Ferreira ${ }^{a}$
}

${ }^{a}$ Faculdade de Ciências Farmacêuticas, Universidade de São Paulo, Av. Prof. Lineu Prestes, 580, 05508-900 São Paulo - SP, Brazil

${ }^{b}$ Instituto de Química, Universidade de São Paulo, CP 26077, 05599-970 São Paulo - SP, Brazil

${ }^{c}$ Centro de Ciências Exatas e Tecnológicas, Universidade Estadual Vale do Acarajú, Av. da Universidade, 850, 62040-370 Fortaleza - CE, Brazil

${ }^{d}$ Faculdade de Ciências Farmacêuticas, Universidade Estadual Paulista, CP 502, 14801-902 Araraquara - SP, Brazil

A doença de Chagas é um grave problema de saúde pública para a América Latina, situação agravada pela inexistência de quimioterapia eficiente. Os dois fármacos comercialmente encontrados, benznidazol e nifurtimox, são eficazes apenas na fase aguda da doença. A nitrofurazona é ativa contra Trypanosoma cruzi, entretanto, a alta toxicidade impede seu uso na parasitose. A hidroximetilnitrofurazona é um pró-fármaco da nitrofurazona, que apresenta maior atividade contra Trypanosoma cruzi, além de ser menos tóxico. Estudou-se o comportamento voltamétrico da nitrofurazona por voltametria cíclica, varredura linear e pulso diferencial, comparando-o ao do metronidazol e do cloranfenicol. Os coeficientes de difusão dos três fármacos foram estimados aplicando-se a equação de Wilke-Chang. Este artigo também apresenta o estudo do derivado hidroximetilnitrofurazona por voltametria cíclica. A redução de nitrofurazona é pH-dependente e em meio ácido o derivado hidroxilamínico, envolvendo quatro elétrons, é o principal produto formado. Em meio alcalino e com prévio tratamento do eletrodo de carbono vítreo, a redução de nitrofurazona ocorre em duas etapas: a primeira envolve um elétron para formar o nitro-radical aniônico e a segunda etapa corresponde à formação da hidroxilamina. Hidroximetilnitrofurazona possui comportamento voltamétrico semelhante e, de forma análoga, apresentou a mesma eletroatividade e capacidade de estabilização do nitro-radical, indicando que a modificação molecular de nitrofurazona não introduziu alterações no seu comportamento voltamétrico. Uma breve discussão das diferenças de atividade biológica entre os compostos também é apresentada.

Chagas' disease is a serious health problem for Latin America. The situation is worsened by the lack of efficient chemotherapy. The two available commercial drugs, benznidazole and nifurtimox, are more effective in the acute phase of the disease. Nitrofurazone is active against Trypanosoma cruzi, however its high toxicity precludes its current use in parasitosis. Hydroxymethylnitrofurazone is a prodrug of nitrofurazone. It is more active against Trypanosoma cruzi than nitrofurazone, besides being less toxic. This work shows the voltammetric behavior of nitrofurazone and a comparison with those of metronidazole and chloramphenicol using cyclic, linear sweep and differential pulse voltammetries. For these drugs also the prediction of the diffusion coefficients using Wilke-Chang equation was performed. The reduction of nitrofurazone is $\mathrm{pH}$-dependent and in acidic medium the hydroxylamine derivative, involving four electrons, is the principal product formed. In aqueousalkaline medium and with a glassy carbon electrode pre-treatment the reduction of nitrofurazone occurs in two steps, the first involving one electron to form the nitro-radical anion and the second corresponding to the hydroxylamine derivative formation. Hydroxymethylnitrofurazone presented the same voltammetric behavior and electroactivity, indicating that the molecular modification performed in nitrofurazone did not change its capacity to be reduced. A brief discussion regarding the differences in biological activity between the two compounds is also presented.

Keywords: nitrofurazone, hydroxymethylnitrofurazone, nitrofurazone prodrug, cyclic voltammetry, nitro-radical anion

* e-mail: scalea@usp.br 


\section{Introduction}

Chagas' disease affects about one quarter of the population of Latin America. According to the World Health Organization, there are about 120 million people living in risk of contracting parasitosis and 16 to 18 million people infected with the parasite. ${ }^{1}$ In Brazil, where about 6 million people are infected, the main problem with treatment is the resistance of Trypanosoma cruzi to nifurtimox. ${ }^{2}$ Furthermore, benznidazole (2-nitroimidazole) is the only drug marketed in Brazil used for the chemotherapy of Chagas' disease. Both drugs are only effective in the acute phase of the disease. ${ }^{2}$

New drug candidates have been proposed for Chagas' disease chemotherapy and other nitroheterocyclic compounds have been tested as antichagasic drugs to face this serious health problem for Latin America. Nitrofurazone (5-nitro-2-furaldehyde semicarbazone, Figure 1) was synthesized based on the knowledge that furoic acid, as well as its derivatives, demonstrates antimicrobial activity, being active against Gram-positive and Gram-negative bacteria. ${ }^{3}$ However, its high toxicity has precluded its use in systemic infections. ${ }^{4}$
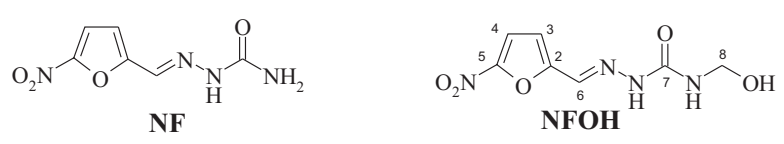

Figure 1. Molecular structures of nitrofurazone (NF) and hydroxymethylnitrofurazone $(\mathrm{NFOH})$.

In contrast, a report has shown that nitrofurazone is also able to destroy $T$. cruzi through trypanothione reductase inhibition, this enzyme is found in the parasite but not in the host. ${ }^{5}$ Based on this finding, and considering the mechanism of action of primaquine which may act by increasing the oxidative stress in the parasite due to free radicals formation, ${ }^{6}$ mutual prodrugs of both drugs were previously synthesized as Mannich bases and shown to be active in vitro in LLC-MK2 cell cultures infected with $T$. cruzi trypomastigotes. ${ }^{6}$ Hydroxymethylnitrofurazone (Figure 1), a new potential prodrug against Chagas' disease, ${ }^{7.8}$ is the intermediate of these compounds. Initial results showed that this derivative is more active against T. cruzi than nitrofurazone, in addition to being less toxic. ${ }^{7,8}$

The biological action of nitroheterocyclic drugs is dependent on the reduction of the nitro group. The nitroradical anion and hydroxylamine derivative are the main intermediate products responsible for the cytotoxic action of some of the nitroheterocyclic compounds. ${ }^{9,10}$ The pharmacological properties of these compounds have been quantitatively related to reduction of the redox couple
$\mathrm{R}-\mathrm{NO}_{2} / \mathrm{R}^{-\mathrm{NO}_{2}}{ }^{-{ }^{-}}$and hydroxylamine formation. ${ }^{10,11}$ Structure-activity relationship studies ${ }^{15}$ demonstrated that the reduction potential correlates with the antimicrobial activity of nitroheterocyclic compounds. Some of these compounds have a trypanocidal action due to either the ability of flavoproteins to reduce the nitrocompound to the nitro-radical or the formation of superoxide and hydrogen peroxide, as a consequence of the electron transfer from the nitro-radical to the molecular oxygen. ${ }^{9,10,16}$ On the other hand, results of electrochemical studies with some 5-nitrofurane and 5-nitrothiophene derivatives were not conclusive enough to explain the differences in trypanocidal activity. All the derivatives presented values close to that of the reduction potential, which indicates similar eletcroactivities. ${ }^{17}$

The electrochemical reduction of nitroheterocyclic compounds follows a complex mechanism. Theoretically, the nitro group can receive up to six electrons in the complete reduction to the amine derivative..$^{9,18}$ Under anaerobic conditions or low oxygen pressure, the reduction process is similar to that observed for nitrobenzene..$^{18} \mathrm{~A}$ total of two electrons and two protons is involved in the formation of the nitroso (R-NO) intermediate, two more electrons and protons result in the hydroxylamine (R-NHOH): ${ }^{13,14,18}$

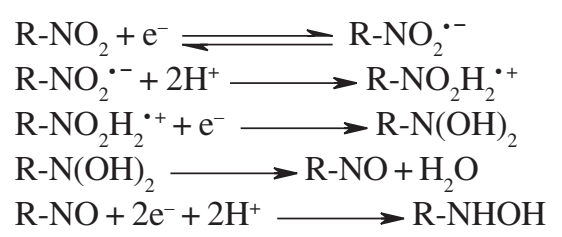

The addition of two more electrons results in formation of the amine:

$\mathrm{R}-\mathrm{NHOH}+2 \mathrm{e}^{-}+2 \mathrm{H}^{+} \longrightarrow \mathrm{R}^{-} \mathrm{NH}_{2}+\mathrm{H}_{2} \mathrm{O}$

Using cyclic voltammetry and aprotic media, nitroradical stabilization can be observed. ${ }^{12-14}$ The cyclic voltammetry studies for nitro-radical formation show that the reduction mechanism depends significantly on the solvent and support electrolyte. Currently, the use of aprotic solvents provokes an expressive decrease in proton availability in the medium, favoring the stabilization of the $\mathrm{R}-\mathrm{NO}_{2}{ }^{--}$radical. ${ }^{12}$ Many reports on the electrochemistry behavior of nitrofurans can be found in the literature..$^{14,19-22}$ The voltammetric behavior of nitrofurazone and its electrochemical determination in pharmaceutical samples have also been registered. ${ }^{23-27}$

In this study, the voltammetric behavior of nitrofurazone, and its hydroxymethyl derivative, on a 
glassy carbon electrode in aqueous media is reported. A comparison with voltammetric behavior of metronidazole (MTZ) and chloramphenicol (CFN) also is presented. Moreover, a discussion about the biological activity of these compounds is also surveyed from the voltammetric results obtained.

\section{Experimental}

\section{Chemicals}

Stock solutions $\left(0.01 \mathrm{~mol} \mathrm{~L}^{-1}\right)$ of nitrofurazone (Avocado Company) and hydroxymethylnitrofurazone were prepared through direct dissolution in deionizade water and ethanol (1:1) using an ultrasonic bath; metronidazole (Rhodia Farma Lda.) and chloramphenicol (Sigma Chemical Co.) through dissolution only in deionizade water. The $\mathrm{pH}$ study was accomplished with universal buffer starting from the mixture of phosphoric, acetic and boric acids with $\mathrm{NaOH} .{ }^{28}$ All solutions were prepared using analytical grade reagents from Merck and purified water from a Barnsted Nanopure UV system.

\section{Hydroxymethylnitrofurazone synthesis}

Hydroxymethylnitrofurazone is not available commercially and its obtainment followed procedure described previously. ${ }^{7,8}$ The synthesis of $\mathrm{NFOH}$ was carried out in alkaline medium. Nitrofurazone $(5.0 \mathrm{mmol}), \mathrm{K}_{2} \mathrm{CO}_{3}$ $(5.0 \mathrm{mmol})$, water $(50 \mathrm{~mL})$ and $18 \mathrm{~mL}$ of formaldehyde were mixed. The reaction was carried out for 49 hours at room temperature, monitored using TLC, following the mobile phase: chloroform:methanol:acetic acid, 85:10:5, $\mathrm{v} / \mathrm{v} / \mathrm{v}$. The suspension formed was then filtered. The resulting product was washed with methanol and recrystallized from methanol/water. Yield 56\%. Melting point: $150-154{ }^{\circ} \mathrm{C}$. Elemental analysis: Calc. C 36.84; H 3.51, N 24.56\%; Found: C 37.20; H 3.26; N 24.09\%. ${ }^{1} \mathrm{H}$ NMR (DMSO-d $) \delta 7.81(\mathrm{~s}, 1 \mathrm{H}, \mathrm{CH}), 7.77-7.75(\mathrm{~d}, 1 \mathrm{H}$, Het$\mathrm{H} ; J$ 3.9), 7.68-7.61 (t, 1H, NH; J 6.3), 7.22-7.20 (d, 1H, Het-H; $J$ 3.9), 4.62-4.59 (d, 1H, CH2; $J$ 6.6); ${ }^{13} \mathrm{C}$ NMR $\left(\mathrm{DMSO}_{6}\right.$ ) $\delta 127.89$ (C2), 112.72 (C3), 115.17 (C4), 151.36 (C5), 152.86 (C6), 154.60 (C7), 63.22 (C8).

\section{Electrochemical assays}

The cyclic, linear sweep and differential pulse voltammograms were recorded using an Autolab PGSTAT 20 potentiostat/galvanostat from Eco-Chimie, Utrecht, Netherlands, coupled to a $20 \mathrm{~mL}$ cell with a system of three electrodes: a glassy carbon (GCE, Metrohm, $\varnothing=2 \mathrm{~mm}$ ) as the working electrode, $\mathrm{Ag} / \mathrm{AgCl}$ as the reference and $\mathrm{Pt}$ as the auxiliary electrode. The acquisition and treatment of data were performed using the GPES 4.3 program (EcoChimie). Dissolved air was removed from the solutions by bubbling with nitrogen for 10 minutes. The $\mathrm{pH}$ control was measured with a Metrohm $654 \mathrm{pH}$-meter and the combinedglass electrode at room temperature.

\section{Pre-treatment of the glassy carbon electrode}

The glassy carbon electrode was manually polished with $0.3 \mathrm{~mm}$ alumina suspension on metalographic paper (Arotec S/A, Brazil). The nitro-radical studies were performed using the same polishing procedure, followed by sonication (10 $\mathrm{min}$ ) in ethanol, using an ultrasonic bath $(40 \mathrm{kHz})$, and rinsed with water.

\section{Prediction of diffusion coefficients}

The diffusion coefficient predictions in aqueous phase with infinite dilution were carried out using the WilkeChang equation: ${ }^{29}$

$D=\frac{7.4 \times 10^{-8}(x \mathrm{M})^{0.5} \mathrm{~T}}{\eta \mathrm{V}^{0.6}}$

where $D$ is the diffusion coefficient of the solute in water $\left(\mathrm{cm}^{2} \mathrm{~s}^{-1}\right) ; \eta$ is the viscosity of water (centipoise) at the temperature of interest $\left(\eta=0.8937\right.$ at $\left.25^{\circ} \mathrm{C}\right),{ }^{30} \mathrm{M}$ is the molar mass of water $\left(\mathrm{g} \mathrm{mol}^{-1}\right)$, T is the temperature $(\mathrm{K}), x$ is the association parameter of water and $\mathrm{V}$ is the Le Bas molar volume of the solute $\left(\mathrm{cm}^{3} \mathrm{~mol}^{-1}\right)$.

The molar volume of the solute was calculated starting from the ratio, empirically determined, ${ }^{31}$ between molecular volume $\left(\mathrm{V}_{\mathrm{W}}\right)$ and the Le Bas molar volume $(\mathrm{V})$ :

$\mathrm{V}_{\mathrm{W}}=1.06 \mathrm{~V}$

The $\mathrm{V}_{\mathrm{w}}$ values (Table 1) were calculated by molecular modeling study using the AM1 semi-empirical method ${ }^{32}$ using the SPARTAN O2 software for Linux, version 119 (Wavefunction Inc.). The $\mathrm{V}_{\mathrm{w}}$ was adopted as that corresponding to the lowest minimum energy conformer (gas phase), obtained after geometric optimization and conformational analysis (systematic search). For the later, the systematic analysis (when possible, up to 91 conformers) and Monte Carlo randomic analysis (above 91 possible conformers) was employed. The molecular volume calculation was performed by the software considering the van der Waals atomic volume, excluding the overlap volumes. 
Table 1. Voltammetric results for reduction of the studied drugs at $\mathrm{pH} 7.45$ using GCE

\begin{tabular}{lccccccc}
\hline Drug & $\mathrm{V}_{\mathrm{w}}$ & $D \times 10^{6}$ & \multicolumn{2}{c}{ DPV } & & LSV $^{\mathrm{a}}$ \\
\cline { 6 - 9 } & $\left(\AA^{3}\right)$ & $\left(\mathrm{cm}^{2} \mathrm{~s}^{-1}\right)$ & $E c_{\mathrm{p} 1}(\mathrm{~V})$ & $I c_{\mathrm{p} 1}(\mu \mathrm{A})$ & $W_{1 / 2}(\mathrm{mV})$ & $E c_{\mathrm{p} 1}(\mathrm{~V})$ & $I c_{\mathrm{p} 1}(\mu \mathrm{A})$ \\
\hline NF & 170.4 & 7.37 & -0.389 & 3.25 & 64.6 & -0.451 & 10.2 \\
MTZ & 160.7 & 7.63 & -0.552 & 3.22 & 68.8 & -0.619 & 10.4 \\
CFN & 269.4 & 5.60 & -0.569 & 2.33 & 69.9 & -0.615 & 9.05 \\
\hline
\end{tabular}

a $[$ Drug $]=0.1 \mathrm{mmol} \mathrm{L}^{-1} ; v=5 \mathrm{mV} \mathrm{s}^{-1} ; \Delta \mathrm{E}=50 \mathrm{mV}$; medium results obtained from 5 runs;

b Linear sweep voltammetry: experimental conditions presented in Figure 3.

The association parameter $x$ is a dimensionless empirical factor characteristic for water (solvent). In this work $x=2.53^{31}$ was used. All the predictions and graphic studies were made using de Origin 7.5 software (OriginLab Corp.).

\section{Results and Discussion}

\section{Voltammetric reduction of nitrofurazone}

The physiological $\mathrm{pH}(7.45)$ was used as a reference for the initial voltammetric tests. The cyclic voltammograms recorded for NF solution showed two irreversible reduction waves and one anodic peak (Figure 2). The first reduction peak $\left(E c_{\mathrm{pl}}=-0.469 \mathrm{~V}\right)$ corresponds to the reduction of the nitro group to the hydroxylamine derivative (peak 1), involving four protons and four electrons, as depicted below.

$\mathrm{R}-\mathrm{NO}_{2}+4 \mathrm{e}^{-}+4 \mathrm{H}^{+} \longrightarrow \mathrm{R}-\mathrm{NHOH}+\mathrm{H}_{2} \mathrm{O}$

The affirmation above could be confirmed by the comparison of the voltammetric results obtained with NF, regarding MTZ and CFN. Both drugs are reduced involving four electrons. ${ }^{12,21}$ Figure 3 shows the linear sweep voltammograms of the studied drugs. This comparison was possible since diffusion coefficient $(D)$ predictions showed these three compounds have similar sizes. Diffusion coefficients depend on the solvent viscosity (water at $25{ }^{\circ} \mathrm{C}$ ) and molar volume of solute. The empirical correlation between $\mathrm{V}$ and $\mathrm{V}_{\mathrm{w}}$ values presented excellent linear relationship, enabling the determination of the molar volume from the volumes calculated by AM1. ${ }^{31}$

Table 1 shows the results obtained by linear sweep voltammetry (LSV) for the studied drugs. NF is more electroactive than MTZ and CFN. However, the current values are much more closely related and this is a good indication that the three drugs are reduced involving the same number of electrons $(n)$. The results correspond to the highest values obtained after successive GCE polishing. The current function $\left(I_{\mathrm{f}}=I c_{\mathrm{pl}} / \mathrm{n}^{1 / 2} C_{\mathrm{O}}\right)$ in LSV

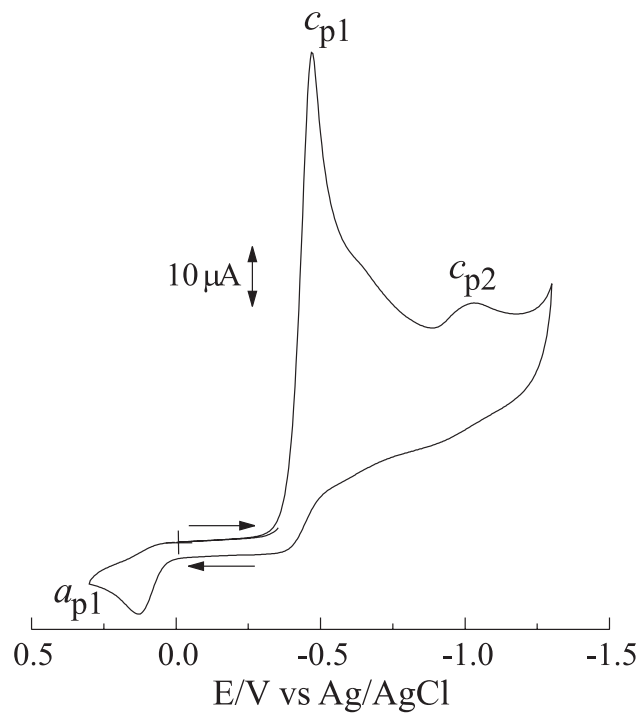

Figure 2. Cyclic voltammogram registered in universal buffer $\mathrm{pH}$ 7.45 and $1.0 \mathrm{mmol} \mathrm{L}^{-1} \mathrm{NF}$ solution, scan rate $=0.1 \mathrm{~V} \mathrm{~s}^{-1}$; working electrode:GCE without sonication pre-treatment; ionic strength = $0.6 \mathrm{~mol} \mathrm{~L}^{-1}$
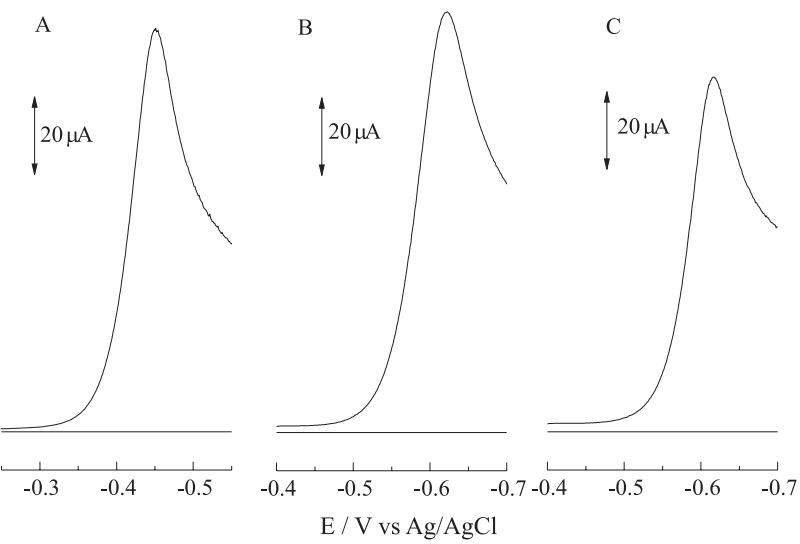

Figure 3. Linear sweep voltammograms registered in universal buffer pH 7.45; (A) $1.0 \mathrm{mmol} \mathrm{L}^{-1} \mathrm{NF}$; (B) $1.0 \mathrm{mmol} \mathrm{L}^{-1} \mathrm{MTZ}$; (C) $1.0 \mathrm{mmol}$ $\mathrm{L}^{-1}$ CFN. Scan rate $=0.01 \mathrm{~V} \mathrm{~s}^{-1}$; working electrode: GCE without sonication pre-treatment; ionic strength $=0.6 \mathrm{~mol} \mathrm{~L}^{-1}$.

depends on $n^{3 / 2}$ and $D^{1 / 2} .{ }^{33}$ Thus, the current function relationship between these drugs $\left(I_{\mathrm{f}} \mathrm{NF} / I_{\mathrm{f}} \mathrm{MTZ}\right.$ and $I_{\mathrm{f}} \mathrm{NF} / I_{\mathrm{f}} \mathrm{CFN}$ ) present similar values to that obtained by the diffusion coefficient relationship. This suggests that the 
$\mathrm{NF}$ reduction involves the same number of electrons as those for MTZ and CFN reductions: $n=4$.

In order to better understand the reduction mechanism of NF, similar experiments are presented using differential pulse voltammetry (DPV, Table 1). For solid electrodes DPV introduces advantages in the study of organic compounds, since they frequently lead to electrode adsorption. Differential pulse methodology can better discriminate effects that are kept constant before and after the pulse application. ${ }^{34}$ The width of the peak at half height is defined as: $W_{1 / 2}=3.52 R T / n F$. $^{34}$ The proximity of the $W_{1 / 2}$ values for NF, MTZ and CFN allows us to confirm that these drugs have similar reduction processes. The other parameters $\left(E c_{\mathrm{p} 1}\right.$ and $\left.I c_{\mathrm{p} 1}\right)$ follow the behavior above described for LSV. The differences of current values can be attributed to the different values of $D$.

From these results, we can conclude that the second reduction wave shown in the Figure 2 corresponds to amine derivative formation, involving two more electrons and two protons (equation 6), with a peak potential $\left(E c_{\mathrm{p} 2}\right)$ at $-1.03 \mathrm{~V}$. In the same cyclic voltammogram an anodic peak $\left(E a_{\mathrm{p} 1}\right)$ was also observed at $0.130 \mathrm{~V}$, related to hydroxylamine oxidation to the nitroso derivative. The nitroso-hydroxylamine couple was not detected at low scan rate values. In these experimental conditions, only CFN has demonstrated this wave $(E a=0.0260 \mathrm{~V}, E c=-0.126 \mathrm{~V})$. For NF, $1.0 \mathrm{mmol} \mathrm{L}^{-1}$, the record of this semi-reversible wave was favored in acidic medium ( $\mathrm{pH} 2)$. For high scan rate $\left(2.0 \mathrm{~V} \mathrm{~s}^{-1}\right) E a_{\mathrm{p} 1}$ was registered at $0.510 \mathrm{~V}$ and $E c_{\mathrm{p} 3}=$ $0.430 \mathrm{~V}$ with current values of $8.60 \mu \mathrm{A}$ and $4.90 \mu \mathrm{A}$, respectively. The hydroxylamine oxidation occurs according to the following reaction:

$$
\mathrm{R}-\mathrm{NHOH} \rightleftharpoons \mathrm{R}-\mathrm{NO}+2 \mathrm{e}^{-}+2 \mathrm{H}^{+}
$$

In contrast, previously results ${ }^{24}$ have shown that NF, in a solvent-electrolyte system containing pyridine and formic acid with tetramethyl-ammonium chloride, produces just one reduction wave involving six electrons to the amine derivative. Thus, the electrolyte composition appears to be a determinant for the reduction process of NF.

Table 2 presents the cyclic voltammetric results of NF at $\mathrm{pH}$ 7.45. The scan rate variation from 0.01 to $2.0 \mathrm{~V} \mathrm{~s}^{-1}$ increases the height of the reduction wave and $E c_{\mathrm{pl}}$ is shifted towards negative potentials. The relationship between cathodic current values $\left(I c_{\mathrm{p} 1}\right)$ and $v^{1 / 2}$ is linear, indicating that the electrodic reaction is diffusion controlled. However, is important to highlight that before each scan the GCE was efficiently polished with alumina, otherwise the current decreased by about by 35 per cent after the first scan. The application of the current function values $\left(I c_{\mathrm{p} 1} / v^{1 / 2} C_{\mathrm{NF}}, v \leq 0.3 \mathrm{~V} \mathrm{~s}^{-1}\right)$ and $D$ value of NF (Table 1) in the Randles-Ševčik equation ${ }^{33,34}$ $\left(I \mathrm{c}_{\mathrm{p} 1}=-2.69 \times 10^{5} \nu^{3 / 2} A D^{1 / 2} C_{\mathrm{NF}} v^{1 / 2}\right)$ can be a good approximation for the number of electrons calculation. From the data of Table 2 a total of four electrons was estimated, corroborating the results presented above.

Table 2. Cyclic voltammetric results for reduction of $1.0 \mathrm{mmol} \mathrm{L}^{-1}$ $\mathrm{NF}$ at $\mathrm{pH} 7.45$ using GCE

\begin{tabular}{lcccc}
\hline $\begin{array}{c}v \\
\left(\mathrm{~V} \mathrm{~s}^{-1}\right)\end{array}$ & $\begin{array}{c}E c_{\mathrm{p} 1} \\
(\mathrm{~V})\end{array}$ & $\begin{array}{c}I c_{\mathrm{p} p} / v^{1 / 2} C_{\mathrm{NF}} \\
\left.(\mathrm{A} \mathrm{mol} \mathrm{s})^{1 / 2} \mathrm{~cm}^{-3} \mathrm{~V}^{-1 / 2}\right)^{*}\end{array}$ & $\begin{array}{c}E c_{\mathrm{p} 1}-E_{\mathrm{p} / 2} \\
(\mathrm{~V})\end{array}$ & $\alpha \mathrm{n}$ \\
\hline 0.010 & -0.456 & 126 & -0.041 & 1.17 \\
0.020 & -0.443 & 177 & -0.036 & 1.33 \\
0.030 & -0.451 & 165 & -0.038 & 1.26 \\
0.050 & -0.456 & 201 & -0.039 & 1.23 \\
0.10 & -0.469 & 206 & -0.040 & 1.20 \\
0.20 & -0.478 & 209 & -0.041 & 1.17 \\
0.30 & -0.491 & 204 & -0.041 & 1.17 \\
0.50 & -0.504 & 216 & -0.053 & 0.91 \\
0.70 & -0.509 & 237 & -0.051 & 0.94 \\
1.0 & -0.518 & 236 & -0.054 & 0.89 \\
1.3 & -0.531 & 243 & -0.061 & 0.79 \\
1.6 & -0.535 & 232 & -0.063 & 0.76 \\
2.0 & -0.549 & 274 & -0.070 & 0.69 \\
\hline$C_{\mathrm{NF}}=1.0 \times 10^{-6} \mathrm{~mol} \mathrm{~cm}^{-3}$. & & &
\end{tabular}

The $\alpha \mathrm{n}$ values were obtained from the voltammetric equation for the irreversible electrochemical reaction $\left(E_{\mathrm{p} / 2}\right.$ $\left.-E_{\mathrm{p}, \mathrm{c}}=48 / \alpha \mathrm{n}\right){ }^{33,34}$ The $\alpha \mathrm{n}$ values suggest the involvement of two electrons in the rate-determining step of the electrode reaction, being, therefore, the formation of nitroso compound the slowest step of the first reduction wave. The reduction potential reflects the transfer of the first or second electron and identical behavior was previously registered for $\mathrm{CFN}^{21}$ and MTZ. ${ }^{12}$ The significant decrease of $\alpha \mathrm{n}$ values indicates that $\mathrm{NF}$ irreversible reduction can be evidenced at higher scan rates. This is because the potential application is faster than the charge transfer process involved in the rate-determining step of the electrode reaction.

\section{Effect of pH on nitrofurazone reduction}

The voltammetric reduction of NF was investigated using a GCE in the range $2.32 \leq \mathrm{pH} \leq 12.1$. The $E c_{\mathrm{p} 1}$ value for the NF reduction wave is shifted to negative values with increasing $\mathrm{pH}$, indicating the existence of an acidbase equilibrium close to the electrochemical reaction, confirming that $\mathrm{H}^{+}$ions are involved in the reduction process (equation 7), as shown in the $E c_{\mathrm{p} 1} v s . \mathrm{pH}$ plots, Figure 4. The NF reduction is $\mathrm{pH}$-dependent with $E c_{\mathrm{p} 1}=-0.206 \mathrm{~V}-0.0349 \mathrm{pH}$. The value of the proton numbers $(p)$ was estimated as 0.71 , indicating that one 


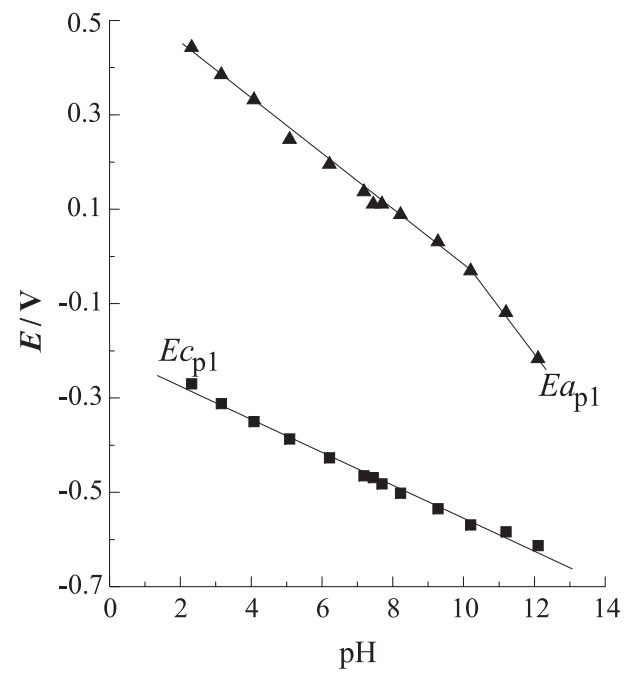

Figure 4. Plot of $E_{\mathrm{p}} v s$. $\mathrm{pH}$ using GCE as a working electrode without sonication pre-treatment: (ם) $E c$, value for the NF reduction wave; $(\boldsymbol{\Delta}) E a_{\mathrm{p} 1}$ values corresponding to hydroxylamine oxidation of the nitroso derivative. $[\mathrm{NF}]=1.0 \mathrm{mmol} \mathrm{L}^{-1}$; $0.1 \mathrm{~mol} \mathrm{~L}^{-1}<$ ionic strength $<1.0 \mathrm{~mol} \mathrm{~L}^{-1}$.

proton is involved in the rate-determining step of the reaction in the $\mathrm{pH}$ range studied. Probably, this result is due to the occurrence of a fast protonation step preceding charge transfer. The $\mathrm{H}^{+}$ion, involved in the ratedetermining reduction step, corresponds to a second slow protonation reaction of the nitro group, which is further reduced to the nitroso intermediate. This reasoning has also been applied to the electrochemical behavior of other nitroheterocyclic drugs. ${ }^{12,21,24}$

On the other hand, it is also possible to make an analysis in which the $E c_{\mathrm{pl}} \mathrm{vs} \mathrm{pH}$ plots presents two linear regions, in acidic medium $(2.32 \leq \mathrm{pH} \leq 7.45)$ with $E c_{\mathrm{p} 1}=-0.188 \mathrm{~V}-0.0384 \mathrm{pH}$ and in alkaline medium (7.69 $\leq \mathrm{pH} \leq 12.1)$ with $E c_{\mathrm{p} 1}=-0.275 \mathrm{~V}-0.0280 \mathrm{pH}$. Although the difference between both regions is very small, this can indicate distinct processes are occurring on the electrode. This could be proved with the surface treatment of the GCE that will be discussed in the next section.

The anodic peak registered (peak 2) is also $\mathrm{pH}$ dependent on the $\mathrm{pH}$ range studied. In alkaline medium, the oxidation is facilitated and the slope of the first linear relationship $\left(E a_{\mathrm{p} 1}=0.569 \mathrm{~V}-0.0593 \mathrm{pH}\right)$ indicates the involvement of the same number of electrons and protons (Figure 4).

\section{Voltammetric generation of nitro-radical anion from nitrofurazone}

At $\mathrm{pH}>8$ a change of the reduction process of NF was observed, because a shoulder around $-0.5 \mathrm{~V}$ preceding the main reduction wave has been registered. In this experimental conditions this behavior change may be related to the reversible reduction of the nitro group to the nitro-radical, involving one electron.

Figure 5 presents the cyclic voltammograms of NF $1.0 \mathrm{mmol} \mathrm{L}^{-1}$ at $\mathrm{pH}$ 12.1. The $\mathbf{C}$ voltammogram clearly shows the unfolding of the NF reduction wave and the appearance of a peak with $E c_{\mathrm{pN}}=-0.490 \mathrm{~V}$. This reduction peak (equation 1) has a corresponding oxidation peak at $-0.419 \mathrm{~V}$, as can be observed from the inset in Figure 5 and corresponds to the nitro-radical formation in a step involving 1e. In the sequence, the nitro-radical is reduced to the hydroxylamine derivative $\left(E c_{\mathrm{p} 1}=-0.708 \mathrm{~V}\right)$, according to the following mechanism:

$$
\mathrm{R}-\mathrm{NO}_{2}{ }^{--}+3 \mathrm{e}^{-}+4 \mathrm{H}^{+} \longrightarrow \mathrm{R}-\mathrm{NHOH}+\mathrm{H}_{2} \mathrm{O}
$$

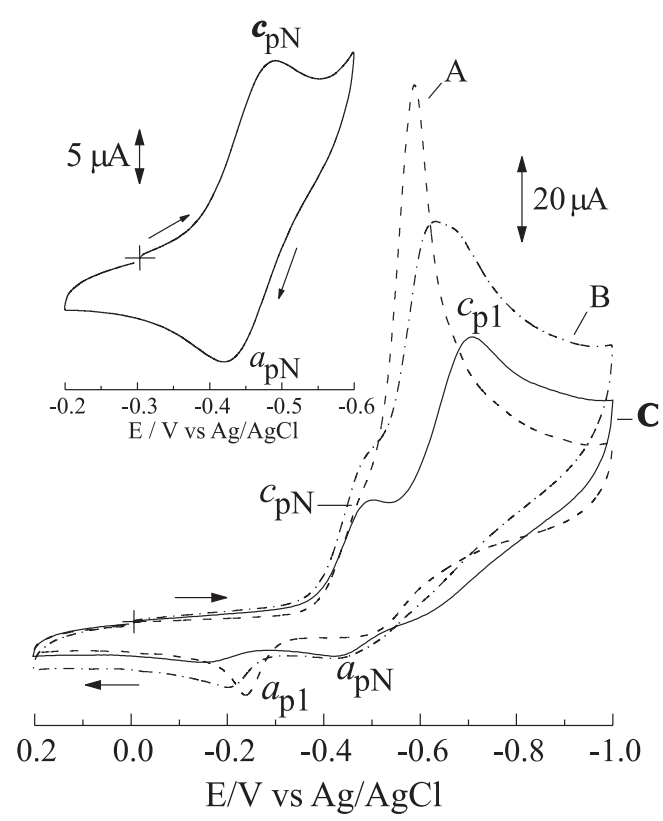

Figure 5. Cyclic voltammograms recorded in universal buffer $\mathrm{pH}$ 12.1 and $1.0 \mathrm{mmol} \mathrm{L}^{-1} \mathrm{NF}$ solution. Scan rate $=1.0 \mathrm{~V} \mathrm{~s}^{-1}$. A (dashed line): GCE polished with $0.3 \mu \mathrm{m}$ alumina; B (dash-doted line): GCE polished with $0.3 \mu \mathrm{m}$ alumina and sonicated in an ultrasonic bath with deionized water; $\mathrm{C}$ (solid line): GCE polished with $0.3 \mathrm{~mm}$ alumina and sonicated in an ultrasonic bath with ethanol. Inset: Cyclic voltammogram corresponding to the $\mathrm{R}-\mathrm{NO}_{2} / \mathrm{R}_{-} \mathrm{NO}_{2}{ }^{\cdot-}$ couple for $1.0 \mathrm{mmol} \mathrm{L}^{-1} \mathrm{NF}$ solution in $\mathrm{pH} 12.1$ using a GCE polished with $0.3 \mathrm{~mm}$ alumina and sonicated in ultrasonic bath with ethanol, scan rate $=1.0 \mathrm{~V} \mathrm{~s}^{-1}$; ionic strength $=1.0 \mathrm{~mol} \mathrm{~L}^{-1}$.

The differences among voltammograms (A, B, C) of Figure 5 are related to the procedures adopted for the cleanup of the GCE surface. After the polishing using alumina the GCE was submitted to sonication in deionized water (curve B) or ethanol (curve C) for complete elimination of the alumina from the electrode surface.

The sonication of the GCE in ethanol was the best condition for detection of the $\mathrm{R}-\mathrm{NO}_{2} / \mathrm{R}-\mathrm{NO}_{2}{ }^{--}$couple, and 
shows that the electrode surface plays an important role in the nitro-radical stabilization. The sonication with ethanol may modify the electrode surface, even though ethanol is a hydrophilic solvent. Despite the long duration of the sonication (10 $\mathrm{min})$ the frequency was low $(40 \mathrm{kHz})$. Longer sonication times do not produce significant differences in this electrochemical behavior. Rubinstein ${ }^{35}$ also registered effects of the GCE immersion in methanol in an ultrasonic bath to study of the nitrobenzene reduction. The demonstration of the voltammetric behavior of NF as well as the differences provoked by sonication on the electrode surface and the use of the others solvents for the GCE pretreatment has been aim of the our workgroup and further studies are planned, since previous reports have $\mathrm{e}^{36,37}$ related the importance of sonication on GCE surface activation.

Table 3 shows the voltammetric results for the $\mathrm{R}-\mathrm{NO}_{2} /$ R-NO ${ }_{2}{ }^{-}$-couple. The reduction peak, $E c_{\mathrm{pN}}$, shifted towards a more negative potential, indicating the existence of a protonation equilibrium before the charge transfer process. Thus, a decrease in the values of $I c_{\mathrm{pN} 0}$ was observed suggesting the stabilization of the $\mathrm{R}-\mathrm{NO}_{2} \mathrm{H}^{+} / \mathrm{R}-\mathrm{NO}_{2} \mathrm{H}_{2} \cdot$ at the lowest $\mathrm{pH}$ values. ${ }^{12}$ Similarly, a linear increase of the anodic current values with $\mathrm{pH}$ would be expected, however, we observed a maximum anodic current value at $\mathrm{pH}$ 10.2.

The current ratio values $\left(I a_{\mathrm{pN} 0} / I c_{\mathrm{pN} 0}\right)$, corresponding to the $\mathrm{R}-\mathrm{NO}_{2} / \mathrm{R}_{-} \mathrm{NO}_{2}{ }^{--}$couple, were established using currents measured with respect to the zero current axis. These results differ from unity, however, we may deduce that the stability of the nitro-radical increased at high $\mathrm{pH}$ due to the difficulty in the protonation process. These results are compatible with those previously recorded. ${ }^{23}$

It is also possible to observe from Figure 5 and by the results of Table 3 that the switching potential currents $\left(I_{\lambda}\right)$ are higher than the $I c_{\mathrm{pN} 0}$ values in all studied cases, showing a strong interference of the second reduction step, corresponding to hydroxylamine formation. The choice of the switching potential $\left(E_{\lambda}=-0.6 \mathrm{~V}\right)$ is important for the recorder of the anodic wave. The best separation $(218 \mathrm{mV})$ between both reduction peaks, $E c_{\mathrm{pN}}$ and $E c_{\mathrm{p} 1}$, was obtained at $\mathrm{pH}$ 12.1. However, the current anodic measurement was jeopardized due to the base line hard correction. Thus, the
$I a_{\mathrm{pN}} / I c_{\mathrm{pN}}$ values calculated using the Nicholson method ${ }^{38}$ were higher than the unity, except at $\mathrm{pH} 12.1$, which incapacitated the kinetics study of nitro-radical disproportionation. ${ }^{39}$

Since the effect of $\mathrm{pH}$ on the protonation process of the species is more complex, shifting the reduction wave to more negative potentials, this situation occurs when protonation process precedes the electron transfer. ${ }^{24}$ This explains the large distance between both reduction peaks at $\mathrm{pH}$ 12.1. The use of mixed medium can improve this separation. ${ }^{22,23}$ On the other hand, the nitro-radical generation in aqueous media can be more useful for further studies with biological targets, in which the experimental conditions should be as close as possible to the biological system.

Similarly to other nitroheterocyclic drugs, ${ }^{13,19,22,23}$ the current ratio $\left(I a_{\mathrm{pN} 0} / I c_{\mathrm{pN} 0}\right)$ increases towards unity as a function of the scan rate, a typical behavior of an irreversible chemical reaction following a charge transfer step. ${ }^{9,39}$ We have assumed that NF undergoes the same mechanism as that proposed by other authors, ${ }^{13,19,22,23}$ as is depicted in the reaction mechanism below:

$$
2 \mathrm{R}^{-\mathrm{NO}_{2}}{ }^{\cdot-}+2 \mathrm{H}^{+} \longrightarrow \mathrm{R}-\mathrm{NO}_{2}+\mathrm{R}-\mathrm{NO}+\mathrm{H}_{2} \mathrm{O}
$$

The generation and electrochemical stabilization of nitro-radical anion in the absence of aprotic solvents enable a reactivity comparison between nitrofurazone and its prodrug. The possible differences in voltammetric behavior of these drugs can be correlated with the pharmacological activities.,

\section{Voltammetric reduction of hydroxymethylnitrofurazone}

$\mathrm{NFOH}$ is a prodrug of NF, that is expected to be released from Mannich bases with primaquine peptides. ${ }^{6-8}$ The hydroxymethylation renders NF more hydrophilic. However, further studies are needed to demonstrate whether this property improves the transport across cell/parasite membrane. ${ }^{8}$

The voltammetric reduction of $\mathrm{NFOH}$ presented the

Table 3. The $\mathrm{pH}$ effect on voltammetric parameters for the $\mathrm{R}-\mathrm{NO}_{2} / \mathrm{R}-\mathrm{NO}_{2}{ }^{--}$couple from $\mathrm{NF}$ reduction. $[\mathrm{NF}]=1.0 \mathrm{mmol} \mathrm{L} \mathrm{L}^{-1} ; v=1.0 \mathrm{~V} \mathrm{~s}{ }^{-1}$; switching potential $\left(E_{\lambda}\right)=-0.6 \mathrm{~V}$

\begin{tabular}{lcccccc}
\hline $\mathrm{pH}$ & $E c_{\mathrm{pN}}(\mathrm{V})$ & $I c_{\mathrm{pN} 0}(\mu \mathrm{A})^{\mathrm{a}}$ & $I a_{\mathrm{pN} 0}(\mu \mathrm{A})^{\mathrm{a}}$ & $I a_{\mathrm{pN} 0} / I c_{\mathrm{pN} 0}$ & $I \lambda(\mu \mathrm{A})^{\mathrm{a}, \mathrm{b}}$ & $I a_{\mathrm{pN}} / I c_{\mathrm{pN}}{ }^{\mathrm{c}}$ \\
\hline 9.28 & -0.473 & 27.3 & 8.19 & 0.30 & 53.0 & 1.33 \\
10.2 & -0.482 & 26.5 & 9.81 & 0.37 & 43.8 & 1.17 \\
11.2 & -0.487 & 20.6 & 8.86 & 0.43 & 30.0 & 1.14 \\
12.1 & -0.490 & 16.7 & 8.02 & 0.48 & 17.5 & 0.988 \\
\hline
\end{tabular}

a current value measured with respect to the zero current axis; ${ }^{\mathrm{b}}$ current value corresponding to the switching potential; ${ }^{\mathrm{c}}$ current ration calculated by the Nicholson method. ${ }^{34}$ 
same NF reduction mechanism at all $\mathrm{pHs}$ studied. The reduction wave corresponds to the hydroxylamine derivative formation $\left(E c_{\mathrm{pl}},=-0.469 \mathrm{~V}\right)$ involving four electrons. The amine formation was also registered at a slightly less negative potential, $E c_{\mathrm{p} 2}$, $=-0.951 \mathrm{~V}$.

Table 4 presents the potential peak values at different $\mathrm{pH}$. The $E c_{\mathrm{pl}}$, values of NFOH show little difference, except at $\mathrm{pH} 7.45$ where both compounds presented exactly the same value. These results indicate that both compounds have similar eletcroactivity, in other words, the molecular modification performed in NF did not change its capacity to be reduced.

Table 4. The peak potentials for $\mathrm{NF}$ and $\mathrm{NFOH}$ at different $\mathrm{pH}$ values. $\mathrm{n}=0.1 \mathrm{~V} \mathrm{~s}^{-1}$

\begin{tabular}{lcc}
\hline $\mathrm{pH}$ & $\mathrm{NFE} c_{\mathrm{p} 1}(\mathrm{~V})$ & $\mathrm{NFOH} E c_{\mathrm{pl}}(\mathrm{V})$ \\
\hline 2.32 & -0.270 & -0.257 \\
6.21 & -0.425 & -0.420 \\
7.45 & -0.469 & -0.469 \\
10.2 & -0.566 & -0.535 \\
12.1 & -0.611 & -0.553 \\
\hline
\end{tabular}

Maintaining the same experimental conditions, i.e., polishing the GCE surface followed by activation in the ultrasonic bath using ethanol, $\mathrm{NFOH}$ was also reduced to $\mathrm{R}_{-} \mathrm{NO}_{2}{ }^{--}$in a step involving one electron. At $\mathrm{pH}$ 12.1, and a scan rate of $1.0 \mathrm{~V} \mathrm{~s}^{-1}$, the $\mathrm{NFOH}$ presented two reduction waves. The potential value for the first peak is $-0.500 \mathrm{~V}$ and the second peak of the hydroxylamine derivative is - $0.704 \mathrm{~V}$ (Figure 6), demonstrating exactly the same

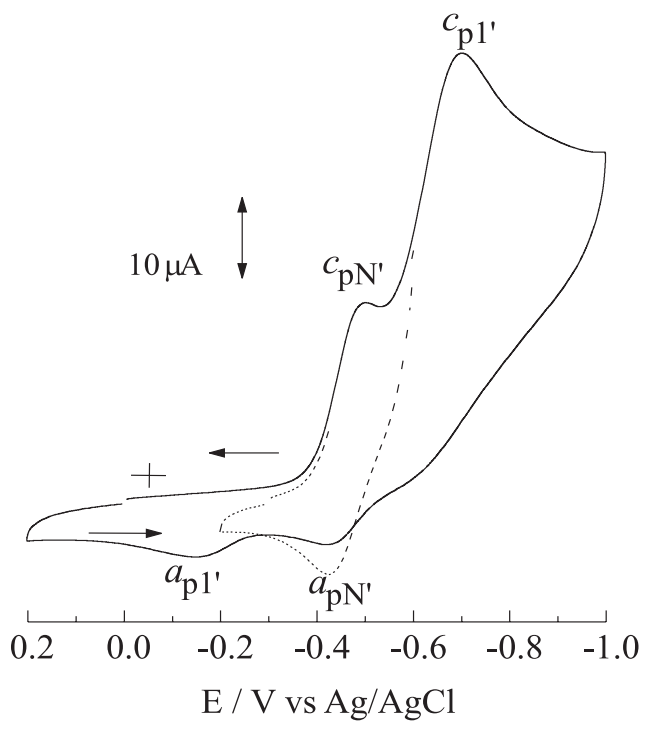

Figure 6. Cyclic voltammograms recorded in universal buffer $\mathrm{pH}$ 12.1 and $1.0 \mathrm{mmol} \mathrm{L}^{-1} \mathrm{NF}$ solution. GCE polished with $0.3 \mathrm{~mm}$ alumina and sonicated in an ultrasonic bath with ethanol and scan rate $=1.0 \mathrm{~V} \mathrm{~s}^{-1}$; ionic strength $=1.0 \mathrm{~mol} \mathrm{~L}^{-1}$. Dashed line is the cyclic voltammogram corresponding to the $\mathrm{R}-\mathrm{NO}_{2} / \mathrm{R}-\mathrm{NO}_{2}{ }^{--}$couple. voltammetric behavior as NF. The quantitative aspects of the electrochemical nitro-radical generation from $\mathrm{NFOH}$ will be the goal of further studies.

As already mentioned, NFOH was synthesized according to the theory that Mannich bases release hydroxymethyl derivatives that are converted to the starting drug. NFOH, however, was shown to be more active than benznidazole and nitrofurazone against trypomastigote and amastigote forms of T. $\mathrm{cruzi}^{8}{ }^{8}$ Furthermore, its toxicity was much lower than NF itself, since this prodrug proved to be less mutagenic (about four times) than the parent drug. ${ }^{29}$ These properties account for the high interest in studying this prodrug under a multidisciplinary viewpoint.

Since the bioactivity and, probably, the toxicity of nitroheterocyclic compounds in protozoa is currently related to the $\mathrm{R}-\mathrm{NO}_{2}$ reduction, the voltammetric studies could explain the higher activity and lower toxicity of a derivative if a significant change in its potential reduction was observed. As NFOH behavior paralleled that of NF, the hydroxymethylation did not change the reduction profile of the latter. Thus, differences of physicochemical properties may be involved in the biological activity and in the toxicity of NFOH to that of NF.

\section{Conclusion}

NF was been reduced on a glassy carbon electrode, producing, in acid medium, only one reduction wave involving four electrons due to the hydroxylamine derivative formation. The activation of the glassy carbon electrode, using polishing with alumina suspension followed by sonication in ethanol, enabled the nitro-radical stabilization in alkaline medium. The study of the nitroradical anion in aqueous media will allow us to study biological targets. NFOH presented the same voltammetric behavior as that of NF, indicating that both compounds have similar electroactivity. On the other hand, $\mathrm{NFOH}$ was shown to be more active and less toxic, in comparison to NF. Whilst the voltammetric study was unable to explain the biological differences between both compounds, voltammetry may be a useful complementary technique for further studies of biological mechanisms.

\section{Acknowledgements}

We thank FAPESP for the financial support (process $\mathrm{n}^{\circ}$. 01/01192-3 and 03/10763-0) and for the posdoctor fellowship to M. A. La-Scalea (process $\mathrm{n}^{\circ}$. 01/09418-0), Capes-Prodoc for the fellowship to C. M. S. Menezes (process $n^{\circ}$. 00019-03-8) and to Richard Compton, from Oxford University, for the suggestions. 


\section{References}

1. WHO; Chagas Disease: Strategic Direction for Research. Disease Burden and Epidemiological Trends, http:// www.who.int/tdr/diseases/chagas/direction.htm, accessed in September 2004.

2. Coura, J.R.; de Castro, S.L.; Mem. Inst. Oswaldo Cruz 2002, 97, 3 .

3. Dodd, M.C.; Stillman, W.B.; J. Pharmacol. Exp.Ther. 1944, $82,11$.

4. Henderson, G.B.; Ulrich, P.; Fairlamb, A.H.; Rosenberg, I.; Pereira, M.; Sela, M.; Cerami, A.; Proc. Natl. Acad. Sci. USA 1988, 85, 5374.

5. Korolkovas, A.; Dicionário Terapêutico Guanabara Ed. 2000/ 2001, Guanabara Koogan: Rio de Janiero, 2002.

6. Gonçalves, M.T.; Chung, M.C.; Colli, W.; Miranda, M.T.M.; Ferreira, E.I.; Rev. Soc. Bras. Med. Trop. 1994, 27, 164.

7. Chung, M.C.; Miranda, M.T.M.; Ferreira, E.I.; Abstracts of $211^{\text {th }}$ American Chemical Society Meeting, New Orleans, USA, 1996.

8. Chung, M.C.; Martinelli, T.F.; Gonçalves, M.T.; Güido, R.V.C.; Varanda, E.A.; Polli, M.C.; Botelho, K.C.; Colli, W.; Miranda, M.T.M.; Ferreira, E.I.; Bioorg. Med. Chem. 2003, 11, 4779.

9. Edwards, D.I. In Comprehensive Medicinal Chemistry. The Rational Design, Mechanistic Study \& Therapeutic Application of Chemical Compounds; Hansch, C.; Sammes, P.G.; Taylor J.B., eds; Pergamon Press: Oxford, 1990, p. 725-751.

10. Viodé, C.; Albuquerque, C.N.; Chauvière, G.; Houée-Lévin, C.; Périe, J.; New J. Chem. 1997, 21, 1331.

11. Guissani, A.; Henry, Y.; Lougmani, N.; Hickel, B.; Free Rad. Biol. Med. 1990, 8, 173.

12. La-Scalea, M.A.; Serrano, S.H.P.; Gutz, I.G.R.; J. Braz. Chem. Soc. 1999, 10, 127.

13. Tocher, J.H.; Gen. Pharmacol. 1997, 28, 485.

14. Núñez-Vergara, L.J.; Squella, J.A.; Aldunate, J.; Letelier, M.E.; Bollo, S.; Repetto, Y.; Morello, A.; Spencer, P.L.; Bioelectrochem. Bioenerg. 1997, 43, 151.

15. Rozenski, J.; De Ranter, C.J.; Verplanken, H.; Quant. Struct.Act. Relat. 1995, 14, 134.

16. Martinez-Merino, V.; Cerecetto, H.; Bioorg. Med. Chem. 2001, 9, 1025 .

17. Cerecetto, H.; Di Maio, R.; González, M.; Risso, M.; Sagrera, G.; Seoane, G.; Denicola, A.; Peluffo, G.; Quijano, C.; Stoppani, A.O.M.; Paulino, M.; Olea-Azar, C.; Basombrío, M.A.; Eur. J. Med. Chem. 2000, 35, 343.
18. Zuman, P.; Microchem. J. 1997, 57, 4.

19. Núñez-Vergara, L.J.; Aldunate, J.; Letelier, M.E.; Bollo, S.; Repetto, Y.; Morello, A.; Spencer, P.L.; Squella, J.A.; Bioelectrochem. Bioenerg. 1995, 38, 355.

20. Squella, J.A.; Lemus, I.; Lonza, G.; Núñez-Vergara, L.J.; Bol. Soc. Chil. Quim. 1991, 36, 109.

21. Morales, A.; Toral, M.I.; Richter, P.; Analyst 1984, 109, 633.

22. Merino, M.; Carbajo, J.; Núñez-Vergara, L.J.; Squella, J.A.; Bol. Soc. Chil. Quim. 2000, 45, 97

23. Symons, T.; Tocher, J.H.; Tocher, D.A.; Edwards, D.I.; Free Rad. Res. Comms. 1991, 14, 33.

24. Morales, A.; Richter, P.; Toral, M.I.; Analyst 1987, 112, 971.

25. Khodari; M.; Mansour, H.; Mersal, G.A.M.; J. Pharm. Biomed. Anal. 1999, 20, 579.

26. Reday, C.S.; Reddy, S.J.; Electroanalysis 1992, 4, 595.

27. Gode, K.D.; Analyst 1985, 110, 1373.

28. Lurie, Ju.; Handbook of Analytical Chemistry, Mir Publishers: Moscow, 1978, p. 263.

29. Wilke, C.R; Chang, P.; A.I.Ch.E. J. 1955, 1, 264.

30. Schramke, J.A.; Murphy, S.F.; Doucette, W.J.; Hintze, W.D.; Chemosphere 1999, 38, 2381.

31. La-Scalea, M.A.; Menezes, C.M.S.; Ferreira, E.I.; Abstracts Book of 27 ${ }^{a}$ Annual Reunion of Brazilian Chemical Society, 2004, abstract FQ-097.

32. Dewar, M.J.S.; Zoebisch, E.G.; Heally, E.F.; Stweart, J.J.P.; J. Am. Chem. Soc. 1985, 107, 3902.

33. Brown, E.R.; Sandifer, J.R. In Physical Methods of Chemistry, Electrochemical Methods 2, Rossiter, B.W.; Hamillton, J.F., eds.; Wiley: New York, 1986, p. 273.

34. Brett, C.M.A.; Brett, A.M.O.; Electrochemistry. Principles, Methods, and Applications, Oxford University Press: Oxford, 1996.

35. Rubinstein, I.; J. Electroanal. Chem. 1985, 183, 379.

36. Zhang, H.; Coury Jr., L.A.; Anal. Chem. 1993, 65, 1552.

37. Marken, F.; Kumbhat, S.; Sanders, G.H.W.; Compton, R.G.; J. Electroanal. Chem. 1996,414, 95.

38. Nicholson, R.S.; Anal. Chem. 1966, 38, 1406.

39. Olmstead, M.L.; Nicholson, R.S.; Anal. Chem. 1969, 41, 862.

Received: September 29, 2004 Published on the web: May 20, 2005

FAPESP helped in meeting the publication costs of this article. 